\title{
The effects of supply chain information integration on organizational performance in food small industry
}

\author{
Sambudi Hamali ${ }^{a^{*}}$, Danang Prihandoko ${ }^{a}$, Shelvy Kurniawan ${ }^{\mathrm{a}}$ and Rani Ramdhani ${ }^{\mathrm{a}}$
}

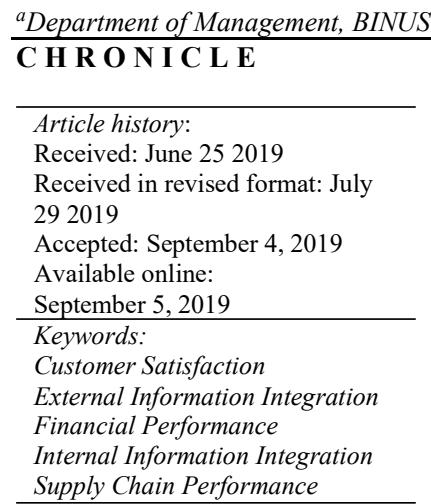
\begin{abstract}
A B S T R A C T
This study aims to examine the effect of supply chain information integration consisting of internal and external Information Integration on organizational performance, which consists of customer satisfaction, supply chain performance, and financial performance. The technique of collecting data is based on a questionnaire distributed to 185 small food industry owners. Methods of data analysis is based on using SEM-PLS. The results show that internal information integration affected customer satisfaction, supply chain, and financial performance. External information integration is proven to have a non-linear effect on customer satisfaction and on the performance of the supply chain. Customer satisfaction and supply chain performance affect financial performance. Internal information integration is more dominant and plays an important role in increasing the performance of the organization.
\end{abstract}

\section{Introduction}

Food and beverage industry is still the mainstay sector supporting the growth of manufacturing in Indonesia. The processing industry contributes to the economic sector. Most of them are non-oil and gas processing industries. Of these industries, food and beverages have the largest portion of the contribution, which is 6.33 percent of national gross domestic product (GDP) in the first semester of 2018 (Movanita, 2018). But throughout 2018 this industry experienced a slowdown in growth. This slowdown is in line with the slowdown in production growth of the Small and Medium-scale food industry, wherein this group there was a slowdown in growth from $7.17 \%$ (YoY) in the first quarter of 2018 to $5.47 \%$ (YoY) in the second quarter of 2018 , furthermore only become $1.64 \%$ (YoY) in the third quarter of 2018 (Kemenperin, 2018). The food industry is an industry that operates in a dynamic business environment, where food reliability is the concern of almost every consumer and government, and the increasing demand for food is produced sustainably (Beske et al., 2014). Food companies must find ways to increase the customer's trust and supply chain partners. Close collaboration with supply chain partners can enhance the company's ability to respond to environmental changes, which at the end can improve company performance. For several companies, sharing information both within the company itself and with its supply chain partners is the key for their companies and supply chain to survive and thrive in a dynamic business environment. In academia, researchers also recognize the importance of information in the supply chain, where this is the starting point to integrate planning of the production, activity's synchronization, joint decision making, and so on, therefore, the capability to get and share information along the supply chain is defined as integration of supply chain information (Huo et al., 2016). The relationship between supply chain information integration (SCII) and performance has been examined in several previous studies. For example, there was a positive relationship between SCII and operational performance (Wong et al., 2015), supply chain performance (Huo et al., 2016; Wu

* Corresponding author. Tel.: +62 81395324099

E-mail address: sambudi hamali@binus.ac.id (S. Hamali) 
et al., 2014), and company performance ( $\mathrm{Li}$ et al., 2014). These studies have explained the importance of SCII in increasing performance. However, previous studies have shown that different dimensions of SCII can play various roles in pursuing different types of performance, among others, the results of research by Yu et al. (2018) explained that dimensions of external and internal information integration affect reactive and proactive flexibility. Furthermore, the only dimension of external information integration indirectly affects operational performance (current assets turnover) through reactive and proactive flexibility. Based on the results of research by Huo et al. (2016), the dimension of the external information integration influences operational efficiency, while the internal information integration affects service quality. Then, from the results of research by Huo et al. (2014) found that the dimensions of information sharing with suppliers do not affect supply chain performance (SCP), while the dimensions of information sharing with internal and customers affect the SCP. The inconsistency of results and doubts about the relationship between performance and SCII shows that this is a very interesting topic to be studied further.

In this study, we chose a food small industry as the object of research. Yu et al. (2018) conducted the integration of supply chain information, flexibility, and operational performance in the food industry. However, Yu et al. (2018) mentioned there were some limitations in their research, such as the dimensions of performance and the limitations of the number of samples. Therefore, they recommend further research to measure other dimensions of performance besides operational performance, such as customer and supplier satisfaction, and adopting larger samples. In this study, performance measures include supply chain performance, customer satisfaction, and financial performance. Based on previous studies, it appears that there is still a gap in the theory to be proven by empirical studies regarding the relationship between supply chain information integration (SCII) and organizational performance. Therefore, the purpose of this study is to determine the direct and indirect effects of SCII dimensions (internal and external information integration) on organizational performance (performance of supply chain, customer satisfaction, and financial performance) in the food small industry.

\section{Literature Review}

\subsection{Supply Chain Information Integration (SCII)}

Sharing information and knowledge is an important contributor to the integrated information flow for two-way communication (Yu et al., 2018). Information is a company asset that is very necessary for companies to get the advantage of costs and services in SCM. Integration of information between organizations and partners of the supply chain is a mechanism for boundaries that facilitate the formation, dissemination, and response to information in the supply chain. The scope of SCII is coordination of supply chain activities with trading partners includes ranging from the development of the products to scheduling of the delivery (Wong et al., 2015). SCII is defined as the condition where producers share information within organizational functions and across partners of the supply chain strategically (through information systems) to manage intraand inter-organizational processes collaboratively (Flynn et al., 2010). Supply Chain Information Integration (SCII) is defined as the extent to which companies focus on exchanging information during transactions or strategically with parties within departments or with supply chain partners outside the enterprise to facilitate streamlining inter-and intra-organizational processes (Yu et al., 2018). Supply Chain Information Integration (SCII) consists of two dimensions, namely internal and external information integration (Huo et al., 2016; Yu et al., 2018).

\subsubsection{Internal Information Integration}

Internal Information Integration refers to the condition where the producers develop information systems which are integrating the company to facilitate the sharing of information among all functions to manage intra-organizational processes (Rai et al., 2006). Internal integration refers to the condition where a company can develop practices, procedures, and behavior in the organization into a synchronized, collaborative and manageable process to meet the requirements of customers (Yu et al., 2018). Based on the perspective of bundling resources, integration of internal information mainly consists of the integration of information systems through the usage of Enterprise Resource Planning (ERP) and other real-time sharing platforms, including information of operating and inventory across intra-organizational functions (Roh \& Hong, 2015; Wang et al., 2016).

\subsubsection{External Information Integration}

External Information Integration (EII) refers to the condition where producers strategically share information with their partners in the supply chain to manage inter-organizational communication through media such as telephone, the internet, or face-to-face (Cai et al., 2010). EII also refers to the condition where the companies can cooperate with key members of the supply chain outside the company, which focuses to develop procedures, strategies, behaviors, and practices among organizations into a process which is synchronized, collaborative, and manageable (Cai et al., 2010). Based on the perspective of the extension of RBV (Resources Base View), integration of external information is defined as the condition where electronic relations are developed for information sharing and communication throughout the inter-organizational process $(\mathrm{Xu}$ et al., 2014; Wong et al., 2013). External integration consists of strategic alliances with customers and also suppliers (Yu et al., 2018). Integration of external information can be divided into two dimensions, they are the integration of customer information and the integration of supplier information (Yu et al., 2018). 


\subsection{Performance}

According to Best (2009), Performance is classified into two groups: they are external (marketing) and internal (financial) performance. If only considering the financial size, the company is relatively unable to carry out external benchmarks of competitive prices, growth of the market, relative products and quality of service, and customer's satisfaction. To complement the internal financial performance and to track market-based performance, businesses need a set of external marketing metrics. Chatzoudes and Chatzoglou (2015) used dimensions of supply chain performance (SCP), customer satisfaction and financial performance. Pambreni et al. (2019) used indicators of organization performance including financial performance, internal or operational performance, customer satisfaction. According to Sofyalogğlu and Oztürk (2012), general performance measurement is divided into two sub-dimensions, they are business performance and operational performance. Business performance has been dealt with two sub-dimensions as market performance and financial performance. On the other hand, operational performance has been evaluated according to several criteria, namely quality, delivery speed and dependence, flexibility, costs, customer service levels, the innovation of product, and the speed of new products to enter the market.

\subsection{Relationship Among Variables dan Hypotheses}

\subsubsection{SCII and Customer Satisfaction (CS)}

Sharing information along the supply chain can improve the level of mutual understanding among the partners of the supply chain, including about expectations and requirements of the customer to ensure that products and services will satisfy the customers' needs (Chatzoudes \& Chatzoglou, 2015). Integration of supply chain information consists of two dimensions, namely internal information integration (III) and external information integration (EII) (Yu et al., 2018). The results of Chatzoudes and Chatzoglou's (2015), study show that customer integration which is measured from a perspective of information sharing has an effect on customer satisfaction, and internal integration which is measured from the perspective of information sharing has an indirect effect on satisfaction of the customers through customer integration which is measured from an information-sharing perspective. Based on the above description, the hypothesis is as follows:

H1. III affects CS.

H2. EII affects CS.

\subsubsection{SCII and Supply Chain Performance (SCP)}

The results of research by Huo et al. (2016) show that EII has an effect on operational efficiency, III has an effect on service quality, which according to Chatzoudes and Chatzoglou (2015), SCP measures include efficiency and service quality (responsiveness, reliability). They argued that supplier integration, internal integration and customer integration measured from information sharing perspective affected SCP. While the results of research by Huo et al. (2014), Internal Information Sharing and Information Sharing with Customers affect SCP. Based on the above description, the hypothesis is as follows:

H3. III affects SCP.

H4. EII affects SCP.

\subsubsection{SCII and Financial Performance (FP)}

$\mathrm{Yu}$ et al. (2013) found that only integration of supplier which has an impact on financial performance, while customer satisfaction fully mediates the relationship between financial performance (FP) and customer integration. Chatzoudes and Chatzoglou (2015) in their study found that integration of customer which measured from an information-sharing perspective, has a direct impact on FP, while internal integration has an indirect effect on FP through SCP and CS. Based on the above description, the hypothesis is as follows:

H5. III affects FP.

H6. EII affects FP.

\subsubsection{CS and Financial Performance (FP)}

The results of the study by Xie et al. (2017) shows that the customers who are satisfied have a positive effect on financial performance. Based on the research of Yu et al. (2013), customer satisfaction is very important for better financial performance, which shows that a very high level of customer service, obtained through strategic partnerships with customers, is likely to offer opportunities for manufacturing success. Based on the above description, the hypothesis is as follows:

\section{H7. CS affects FP.}

\subsubsection{SCP and Financial Performance (FP)}

The impact of performance of the supply chain (SCP) on financial performance is still instantiated in few studies in the context of SCII. The results of the study by Chatzoudes and Chatzoglou (2015) show that SCP influences financial performance. Based on the above description, the hypothesis is as follows:

$\mathrm{H}_{8}$ : SCP affects FP. 
Furthermore, the research model in more details is shown in Fig. 1 as follows.

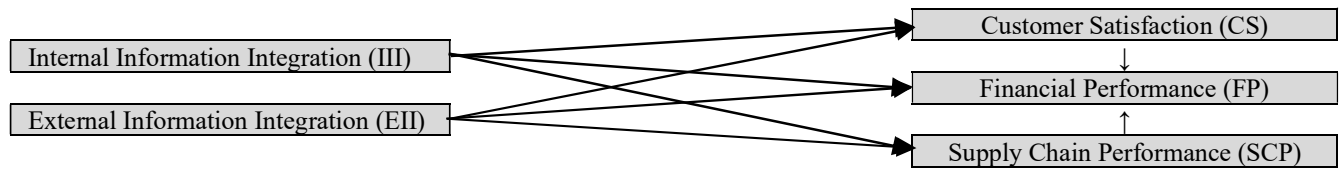

\section{Methodology}

Fig. 1. Research Model

The population in this study are the food small industries in the province of DKI Jakarta, Indonesia. The number of food small industries in DKI Jakarta Province is 3,545 industries. Of the 195 small industries that filled out the questionnaire, only 185 filled in correctly and completely, so the number of samples was 185 food small industries. This number has exceeded the practical rules of PLS-SEM that the minimum sample size must be 10 times the maximum number of arrows that point to latent variables anywhere in the PLS path model (Hair et al., 2014). Primary data is collected through surveys obtained by distributing questionnaires directly to respondents. Measurements of all research constructs (integration of internal and external information, customer satisfaction, the performance of supply chain, and financial performance) were carried out using several question items adopted from international literature. Items for measuring internal and external information integration were adopted from Huo et al. (2016), where internal information integration (4 items) and external information integration (4 items). Items to measure the satisfaction of the customers, the performance of the supply chain, financial performance adopted from Chatzoudes and Chatzoglou (2015), with customer satisfaction (4 items), supply chain performance (4 items), and financial performance ( 2 items). The six-point Likert scale used to measure all factors where 1 means strongly disagree, and 6 means strongly agree.

\section{Results}

The conceptual framework testing uses the technique of "Structural Equation Modeling-Partial Least Square" (SEM-PLS). In the SEM-PLS, two measurement models have been carried out: the measurement model (outer model) and the structural model (inner model). To do the appropriate analysis, this study was conducted using WarpPLS 5.0 software.

\subsection{Measurement Model}

In the measurement model, each item is tested for its validity and reliability. Each item is said to be valid if the loading value of each indicator in the construct must be above 0.7, p-value $<0.05$ (Hair et al., 2014); average variance extracted values (AVEs) are often recommended at 0.5 (Kock, 2015) and the square root of the AVEs is higher than the correlation involving latent variables. Each latent variable is said to be reliable if one of the composite reliabilities (CR) or Cronbach alpha (CA) coefficients must has a value at the limit of 0.6 (Kock, 2015). Table 1 shows the values of loading values, AVEs, the square root of the AVEs, CR, and CA from all variables.

Table 1

Construct Validity and Reliability

\begin{tabular}{|c|c|c|c|c|c|c|c|}
\hline Variable & Items & Loading factor & p-value & AVEs & sq. rts. of & $\mathbf{C R}$ & $\mathbf{C A}$ \\
\hline \multirow{4}{*}{ III } & 1 & 0.982 & $<0.001$ & & & & \\
\hline & 2 & 0.975 & $<0.001$ & 0.957 & 0.978 & 0.989 & 0.985 \\
\hline & 3 & 0.982 & $<0.001$ & & & & \\
\hline & 4 & 0.975 & $<0.001$ & & & & \\
\hline \multirow{4}{*}{ EII } & 1 & 0.943 & $<0.001$ & & & & \\
\hline & 2 & 0.941 & $<0.001$ & 0.866 & 0.931 & 0.963 & 0.948 \\
\hline & 3 & 0.911 & $<0.001$ & & & & \\
\hline & 4 & 0.928 & $<0.001$ & & & & \\
\hline \multirow{4}{*}{$\mathrm{CS}$} & 1 & 0.846 & $<0.001$ & & & & \\
\hline & 2 & 0.864 & $<0.001$ & 0.758 & 0.871 & 0.926 & 0.894 \\
\hline & 3 & 0.892 & $<0.001$ & & & & \\
\hline & 4 & 0.881 & $<0.001$ & & & & \\
\hline \multirow{4}{*}{$\mathrm{SCP}$} & 1 & 0.839 & $<0.001$ & & & & \\
\hline & 2 & 0.602 & $<0.001$ & 0.499 & 0.706 & 0.792 & 0.651 \\
\hline & 3 & 0.506 & $<0.001$ & & & & \\
\hline & 4 & 0.820 & $<0.001$ & & & & \\
\hline \multirow[t]{2}{*}{ FP } & 1 & 0.964 & $<0.001$ & 0.930 & 0.964 & 0.964 & 0.925 \\
\hline & 2 & 0,964 & $<0.001$ & & & & \\
\hline
\end{tabular}

Based on the table above, all statistical steps extracted from this analysis are in a satisfactory (valid and reliable) level.

\subsection{Structural model}

In the structural model, the ability to predict the model and the relationship between constructs are examined. 
In the structural model, the ability to predict the model and the relationships between constructs are tested. At this stage, a structural model is tested which includes: the significance of the path coefficient, the value of $\mathrm{R}^{2}$, the effect size $\left(\mathrm{f}^{2}\right)$ and the predicted value $\left(\mathrm{Q}^{2}\right)$.

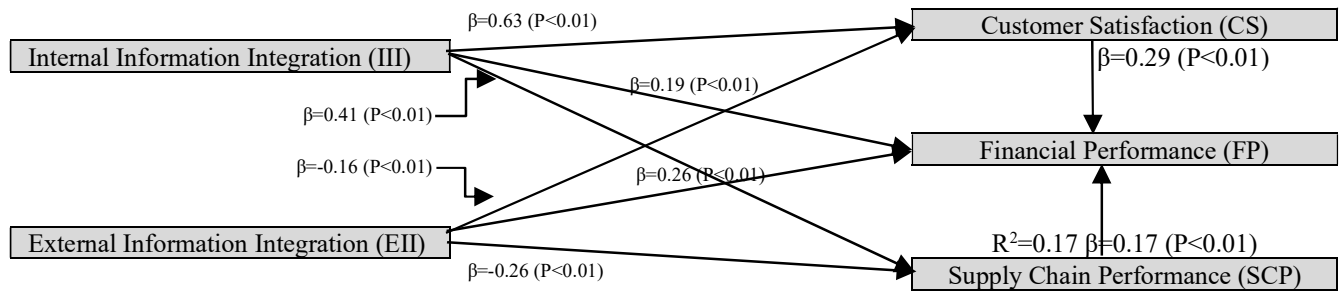

Fig. 2. Result of the structural model

Table 2

Result of the structural model

\begin{tabular}{|c|c|c|c|c|c|}
\hline Hypothesis & Path & Coefficient & p-value & $\begin{array}{c}\mathbf{f}^{2} \\
\text { Effect Size }\end{array}$ & Result \\
\hline H-1 & $\mathrm{III} \rightarrow \mathrm{CS}$ & 0.626 & $<0.001$ & 0.456 & Ho Rejected \\
\hline $\mathrm{H}-2$ & $\mathrm{EII} \rightarrow \mathrm{CS}$ & -0.132 & 0.034 & 0.082 & Ho Rejected \\
\hline $\mathrm{H}-3$ & $\mathrm{III} \rightarrow \mathrm{SCP}$ & 0.414 & $<0.001$ & 0.237 & Ho Rejected \\
\hline $\mathrm{H}-4$ & $\mathrm{EII} \rightarrow \mathrm{SCP}$ & -0.258 & $<0.001$ & 0.132 & Ho Rejected \\
\hline H-5 & $\mathrm{III} \rightarrow \mathrm{FP}$ & 0.190 & 0.004 & 0.089 & Ho Rejected \\
\hline H-6 & $\mathrm{EII} \rightarrow \mathrm{FP}$ & -0.046 & 0.262 & 0.015 & Ho Accepted \\
\hline $\mathrm{H}-7$ & $\mathrm{CS} \rightarrow \mathrm{FP}$ & 0.289 & $<0.001$ & 0.156 & Ho Rejected \\
\hline $\mathrm{H}-8$ & $\mathrm{SCP} \rightarrow \mathrm{FP}$ & 0.235 & $<0.001$ & 0.115 & Ho Rejected \\
\hline
\end{tabular}

In hypotheses 1 and 2, the dimensions of SCII, namely III and EII significantly influence CS. III has a significant positive effect on CS (direct effect $=0.456$ ), so the better information integration in the internal environment, customer satisfaction increases, this means that the better the company is compiling organizational practices, procedures, and behavior, the better collaborative, synchronized, and can be managed. This result is not in line with Chatzoudes and Chatzoglou (2015), where, in their research, the internal integration measured from sharing of information perspective had no impact on the satisfaction of the customers. Meanwhile, EII has a significant negative effect on CS (direct effect $=0.082$ ), so the better the integration of information with the internal environment, the lower customer satisfaction. It can be explained that an environment with rich information can reduce the speed of sense-making, because analysts should sort out and give insight to the data that is often not directly comparable, besides processing too much information can overwhelm the cognitive capacities of decisionmakers, because of the long-time spent for analyzing the information. This information may be outdated when the data is synthesized, so their response in conducting searches is limited and making decisions that do not satisfy consumers (Carbonell $\&$ Escudero, 2010). These results are not in line with Chatzoudes and Chatzoglou (2015), where, in their research, the external integration of information sharing perspective affects customer satisfaction. Based on the results of the WarpPLS analysis it is known that this relationship is non-linear (U-curve), as can be presented in Fig. 3.

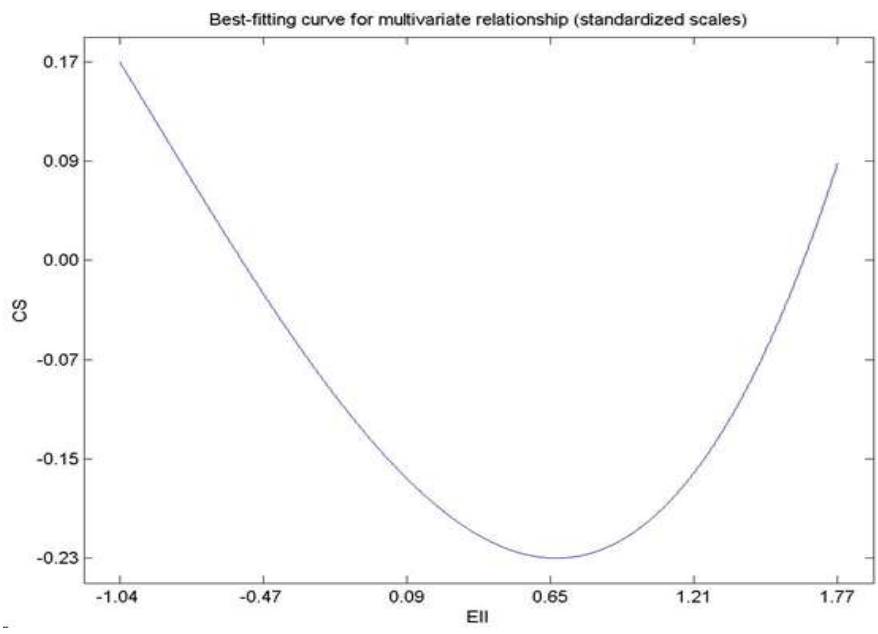

Fig. 3. Non-linear (U-curve) relationship EII to CS 
For the results of this study and previous research, we conclude that external information integration will affect customer satisfaction which is positive. However, there is a limit to the amount of information collected and shared helping the process to satisfy customer needs, beyond that the integration of external information may reduce the customer satisfaction. This finding requires additional empirical verification and further studies. In hypotheses 3 and 4, III and EII significantly influence SCP. III has a significant positive effect on SCP (direct effect $=0.237$ ), so the more information integration in the internal environment increases, the higher SCP, which means better sharing of information among all functions to manage processes in intra-organizational, more flexibility, less lead time and inventory increase, and more reliable shipping. This result is in line with Huo et al. (2014), Chatzoudes and Chatzoglou (2015), and Huo et al. (2016). Meanwhile, EII has a significant negative effect on SCP (direct effect $=0.132$ ), so the better the integration of information with the external environment, the less SCP. This result is not in line with Chatzoudes and Chatzoglou (2015). Based on the results of the WarpPLS analysis, it is known that the relationship between EII and SCP is non-linear (U-curve), as can be seen in Fig. 4.

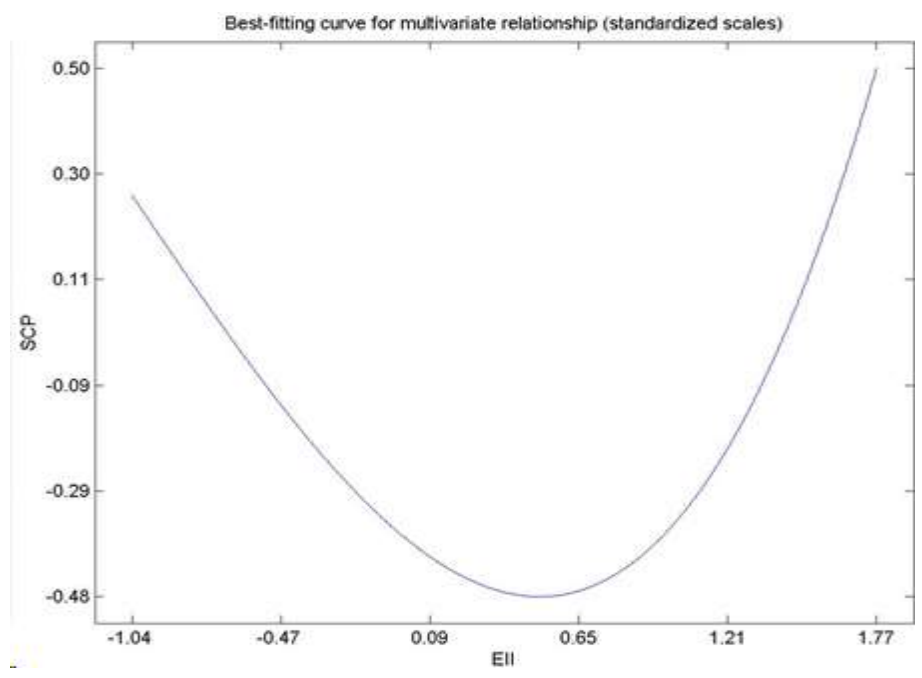

Fig. 4. Non-linear (U-curve) relationship EII to SCP

Based on the results of this research and previous research, as well as the influence of EII on CS, we conclude that there is a limit on the amount of information collected and shared to assist the flow of increasing SCP, beyond that, external information integration might reduce SCP. This finding requires additional empirical verification and future research. In hypothesis 5, III has a significant positive effect both directly and indirectly on FP (direct effect $=0.089$ and total effect $=0.220$ ), so the more information integration in the internal environment, the higher level of FP, which means that integration of internal information is a factor that is important in improving financial performance. This result is in line with Huo et al. (2014), Chatzoudes and Chatzoglou (2015), and Huo et al. (2016). In hypothesis 6, EII does not significantly influence either directly or indirectly towards FP. This result is not in line with Chatzoudes and Chatzoglou (2015), where customer integration from information sharing perspective had a direct effect on FP. In hypothesis 7, CS has a significant impact on FP which is positive (direct effect $=0.156$ ). This means satisfied customers increase the number of similar transactions, thereby increasing sales and profits. This result is in line with Xie et al. (2017). In hypothesis 8, SCP has a significant impact on FP which is positive (direct effect $=0.115$ ). This means satisfied customers increase the number of similar transactions, thereby increasing sales and profits. This result is in line with Xie et al. (2017). In general, the ability of the measurement model to predict is about $17 \%$ of the variance in financial performance $\left(\mathrm{R}^{2}=0.17\right)$. Meanwhile, the ability of the model to predict the phenomenon under study (Q2) is $34.4 \%$

\section{Conclusions}

Based on the results of this research, III has a positive and significant effect on CS, SCP, and FP, while EII has a negative (non-linear) effect on CS and SCP and does not have a direct or indirect influence on FP. Furthermore, both CS and SCP affect FP. This study implies that III is more dominant and has an important role in improving organizational performance. Given the results of the study that EII has a negative (non-linear) influence on CS and SCP, it is necessary to add additional empirical verification and future research on this matter. Besides, according to Huo et al. (2016), EII can cover more dimensions, such as customers and suppliers II, which can show various characteristics and have various impacts on the performance. So, future research needs to classify EII as a customer and supplier Information Integration.

\section{Acknowledgment}

The authors want to thank Bina Nusantara University. This research is supported by the Research Fellowship Bina Nusantara University, the year 2019. 


\section{References}

Beske, P., Land, A., \& Seuring, S. (2014). Sustainable supply chain management practices and dynamic capabilities in the food industry: A critical analysis of the literature. International journal of production economics, 152, 131-143.

Best R. J. (2009). Market-Based Management: Strategy for Growing Customer Value and Profitability. New Jersey : Pearson Education Inc.

Cai, S., Jun, M., \& Yang, Z. (2010). Implementing supply chain information integration in China: The role of institutional forces and trust. Journal of Operations Management, 28(3), 257-268.

Carbonell, P., \& Rodriguez Escudero, A. I. (2010). The effect of market orientation on innovation speed and new product performance. Journal of Business \& Industrial Marketing, 25(7), 501-513.

Chatzoudes, D., \& Chatzoglou, P. (2015). Supply Chain Integration (SCI) measured from an information sharing perspective: Examining its impact on business success. In Research Challenges in Information Science, (pp. 52-63).

Flynn, B.B., Huo B., Zhao X. (2010). The impact of supply chain integration on performance: A contingency and configuration approach. Journal of Operations Management, 28, 58-71.

Hair, J. F., Hult, G. T. M., Ringle, C. M., \& Sarstedt, M. (2014). A Primer on Partial Least Squares Structural Equation Modeling (PLS-SEM). Los Angeles: Sage.

Huo, B., Zhao, X. and Zhou, H. (2014). The effects of competitive environment on supply chain information sharing and performance: an empirical study in China. Production and Operations Management, Vol. 23 No. 4, pp. 552-569.

Huo, B., Han, Z., \& Prajogo, D. (2016). Antecedents and consequences of supply chain information integration: a resourcebased view. Supply Chain Management: An International Journal, 21(6), 661-677.

Jakarta Open Data, (2019). Data Daftar Sentra Industri Kecil dan Menengah di Jakarta. Retrieved 1/6/2019 from http://data.jakarta.go.id.

Kemenperin. (2018). Analisis Perkembangan Industri Edisi IV-2018. Diakses tanggal 6/1/2019 melalui http://www.kemenperin.go.id/kinerja-industri.

Kock, N. (2015). WarpLPS 5.0 User Manual. Third edition. Texas: ScriptWarp SystemTM.

Leuschner, R., Rogers, D. S., \& Charvet, F. F. (2013). A meta-analysis of supply chain integration and firm performance. Journal of Supply Chain Management, 49(2), 34-57.

Li, Y., Ye, F. and Sheu, C. (2014). Social capital, information sharing and performance. International Journal of Operations \& Production Management, Vol. 34 No. 11, pp. 1440-1462.

Movanita, A. M. K. (2018). Sektor Makanan dan Minuman Berkontribusi Terbanyak dalam Industri. Diakses tanggal 6/1/2019 melalui https://ekonomi.kompas.com/read/2018/10/23/140254226/sektor-makanan-dan-minumanberkontribusi-terbanyak-dalam-industri

Pambreni, Y., Khatibi, A., Azam, S., \& Tham, J. (2019). The influence of total quality management toward organization performance. Management Science Letters, 9(9), 1397-1406.

Rai, A., Patnayakuni, R. and Nainika, S. (2006). Firm performance impacts of digitally enabled supply chain integration capabilities. MIS Quarterly, 30(2), 225-246.

Roh, J.J. and Hong, P. (2015). Taxonomy of ERP integrations and performance outcomes: an exploratory study of manufacturing firms. Production Planning \& Control, Vol. 26 No. 8, pp. 1-20.

Sofyalığlu, Ç., \& Öztürk, Ş. (2012). Meta analysis of the relationship between supply chain integration dimensions and firm performance. European Journal of Economics, Finance and Administrative Sciences, 52(September), 99-119.

Wang, Z., Huo, B., Qi, Y. and Zhao, X. (2016). A resource-based view on enablers of supplier integration: evidence from China. Industrial Management \& Data System, 116(3), 416-444.

Wong, C.W.Y., Wong, C.Y., \& Boonitt, S. (2013). The combined effects of internal and external supply chain integration on product innovation. International Journal of Production Economics, 146(2), 566-574.

Wong, C.W.Y., Lai, K.-h. and Bernroider, E.W.N. (2015), The performance of contingencies of supply chain information integration: the roles of product and market complexity. International Journal of Production Economics, $165,1-11$.

Wu, I.-L., Chuang, C.-H. and Hsu, C.-H. (2014), Information sharing and collaborative behaviors in enabling supply chain performance: a social exchange perspective. International Journal of Production Economics, 148, 122-132.

Xie, X., Jia, Y., Meng, X., \& Li, C. (2017). Corporate social responsibility, customer satisfaction, and financial performance: The moderating effect of the institutional environment in two transition economies. Journal of Cleaner Production, 150, 26-39.

$\mathrm{Xu}$, D., Huo, B. and Sun, L. (2014). Relationships between intra-organizational resources, supply chain integration and business performance. Industrial Management \& Data Systems, 114(8), 1186-1206.

Yu, K., Luo, B. N., Feng, X., \& Liu, J. (2018). Supply chain information integration, flexibility, and operational performance: An archival search and content analysis. The International Journal of Logistics Management, 29(1), 340-364.

Yu, W., Jacobs, M. A., Salisbury, W. D., \& Enns, H. (2013). The effects of supply chain integration on customer satisfaction and financial performance: An organizational learning perspective. International Journal of Production Economics, $146(1), 346-358$. 
(C) 2020 by the authors; licensee Growing Science, Canada. This is an open access article distributed under the terms and conditions of the Creative Commons Attribution (CCBY) license (http://creativecommons.org/licenses/by/4.0/). 